\title{
PENGARUH KELEKATAN DAN KOMUNIKASI DENGAN ORANG TUA TERHADAP KARAKTER REMAJA PERDESAAN
}

\author{
Zervina Rubyn Devi Situmorang ${ }^{1 *}$, Dwi Hastuti $^{2}$, Tin Herawati ${ }^{2}$ \\ ${ }^{1}$ PT. Pulau Mahoni, Tempo Scan Pacific Tbk, Jakarta, 12950, Indonesia \\ 2 Departemen IImu Keluarga dan Konsumen, Fakultas Ekologi Manusia, Institut Pertanian Bogor, \\ Bogor 16680, Indonesia
}

*) E-mail: zervinaruby@gmail.com

\begin{abstract}
Abstrak
Interaksi orang tua dan anak yang positif, yang dicerminkan dari komunikasi positif dan kelekatan yang aman, akan berdampak pada perkembangan karakter remaja. Penelitian ini bertujuan untuk mengetahui pengaruh komunikasi serta kelekatan remaja dengan orang tua terhadap karakter remaja di perdesaan. Pemilihan lokasi dilakukan secara purposive di Kabupaten Bogor. Sebanyak 109 remaja yang terdiri atas 43 perempuan dan 66 laki-laki terpilih menjadi responden menggunakan teknik proportional stratified random sampling dari sekolah terpilih di lokasi penelitian. Pengambilan data dilakukan menggunakan teknik self report dengan bantuan kuesioner. Responden dalam penelitian diminta untuk mengisi kuesioner pengembangan dari Parent-Adolescent Communication Scale, Adolescent Attachment Questionnaire, serta VIA-Youth. Data dianalisis dengan analisis deskriptif, uji korelasi, dan uji regresi. Hasil penelitian menunjukkan bahwa skor kelekatan, komunikasi, serta karakter remaja perdesaan masih rendah. Hasil analisis regresi menunjukkan bahwa tidak ada pengaruh yang signifikan antara kelekatan remaja dan orang tua terhadap seluruh dimensi karakter remaja. Sebaliknya, ditemukan pengaruh komunikasi antara orang tua dan remaja yang positif pada dimensi perasaan moral, tindakan moral, dan karakter secara keseluruhan.
\end{abstract}

Kata kunci: karakter, kelekatan, komunikasi, moral, remaja

\section{Abstract \\ The Influence of Attachment and Communication with Parents on Teenager's Character Development in Rural Area}

Positive parent-child interaction, that is characterized by positive communication and secured attachment, will affect teenager's character development. This study aimed to analyze the effect of attachment and communication with parents on teenager's character development in rural area. A total of 109 teenagers consist of 43 girls and 66 boys were selected using proportional random sampling technique in selected school in study site. Data were collected through self-report techniques by questionnaire. Respondents were asked to fill out questionnaires of the Parent-Adolescent Communication Scale, Adolescent Attachment Questionnaire, and VIAYouth to measure attachment with parents, communication with parents, and adolescent character. Data were analyzed with descriptive analysis, correlation, and regression. The results showed that the scores of the attachment, communication, and teenager's characters in rural areas were significantly low. Regression analysis showed that there was no significant effect between teenager's attachment to parents on all dimensions of adolescent characters. Instead, it was discovered that communication between parent and teenager are positively affected on the dimensions of moral feeling, moral action, and overall characters.

Keywords: character, attachment, communication, moral, teenager

\section{PENDAHULUAN}

Masa remaja adalah masa yang penuh dengan perubahan hampir pada setiap aspek perkembangan dalam diri seseorang. Masa ini ditandai dengan peningkatan kemandiran seseorang menjadi individu yang lebih mandiri atau dikenal sebagai istilah autonomy (Keijsers et al., 2010). Pada masa ini remaja melalui tahapan perkembangan kepribadian dan karakter. Kemampuan berpikir remaja sudah sampai pada tahapan formal operational sehingga level moral seseorang diharapkan semakin meningkat. Kematangan moral sangat berkaitan dengan kekuatan karakter yang dimiliki oleh remaja.

Karakter adalah hal yang universal dan dapat dijelaskan oleh berbagai macam aspek yang ada dalam kehidupan bermasyarakat. Karakter 
dapat dikatakan baik apabila yang tergambar dari diri seseorang adalah nilai-nilai atau sifat kebaikan. Kebaikan ini diterima oleh masyarakat dan diterapkan pada setiap aspek kehidupan (Lickona, 2004). Seseorang mengembangkan karakter yang baik dengan cara mengetahui mana yang baik dan tidak dalam berperilaku. Menurut Lickona (1994), seseorang yang berkarakter adalah orang yang mengetahui kebaikan, mencintai kebaikan, serta melakukan kebaikan. Karakter yang baik merupakan sesuatu yang bisa dikembangkan dan pengembangan itu sangat mungkin dilakukan. Hal utama yang perlu dipersiapkan dalam membangun karakter seseorang adalah lingkungan yang penuh kasih sayang.

Karakter merupakan salah satu aspek perkembangan yang banyak mendapat perhatian peneliti belakangan ini. Hasil penelitian sebelumnya memperlihatkan bahwa karakter yang baik memberikan dampak yang baik pula bagi perkembangan serta perilaku seseorang. Seseorang yang memiliki kekuatan karakter secara empiris terbukti memiliki kepuasan hidup yang tinggi dan juga kebahagiaan dalam hidup (Shoshani \& Slone, 2012; Toner et al., 2012; Brdar \& Kashdan, 2010). Karakter yang baik akan menghindarkan seseorang dari perilaku yang tidak baik. Akan tetapi, untuk membentuk karakter yang baik banyak hal yang perlu dilakukan oleh orang tua. Orang tua memiliki tanggung jawab besar untuk menciptakan lingkungan pengasuhan yang kondusif (Berns, 2011). Menurut Lickona (1994), apabila orang tua dapat menciptakan lingkungan pengasuhan yang penuh cinta dan rasa aman maka dapat membantu perkembangan karakter anak secara maksimal.

Lingkungan perkembangan yang kondusif diperlukan untuk dapat membentuk karakter yang baik. Hasil penelitian terdahulu memperlihatkan bahwa kelekatan merupakan salah satu aspek yang ditemukan memengaruhi karakter seorang individu. Penelitian mengenai pengaruh kelekatan terhadap karakter sudah pernah dilakukan mulai dari anak usia dini sampai dengan remaja. Hasil menunjukkan bahwa pengalaman tentang kelekatan yang dimiliki seseorang pada setiap fase kehidupannya akan memengaruhi identitas moral seseorang (Dewanggi et al., 2015; Selby, 2000; Van ljzendoorn \& Zwart-Woudstra, 1995).

Pada penelitian tentang karakter, ada satu aspek yang juga memiliki pengaruh besar yaitu komunikasi (Meeus et al., 2002). Komunikasi yang efektif ditemukan memiliki pengaruh positif terhadap kelekatan, selain itu komunikasi yang baik dapat membantu seorang remaja mengontruksi pengetahuan moralnya (Oladipo, 2009). Hal tersebut dikarenakan komunikasi yang terbuka dan responsif akan memudahkan orang tua untuk mentransmisikan nilai-nilai kebaikan (Speicher, 1994). Komunikasi yang tidak berjalan dengan baik antara remaja dengan orang tua dapat memicu perilakuperilaku negatif. Salah satu di antaranya adalah penelitian tentang kasus bunuh diri remaja usia 11 sampai dengan 18 tahun di Hong Kong. Penelitian tersebut menemukan bahwa komunikasi yang buruk antara orang tua dan remaja dapat memicu rasa putus asa pada remaja yang berujung tindakan bunuh diri (Lai Kwok \& Shek, 2010). Pada akhirnya komunikasi menjadi salah satu aspek penting dalam hubungan antara orang tua dan anak untuk mencegah perilaku-perilaku menyimpang (Blake et al., 2001).

Remaja merupakan komponen bangsa yang diharapkan menjadi generasi penerus bangsa Indonesia. Sebagai penerus bangsa, seorang remaja haruslah memiliki kualitas diri yang prima agar dapat memberikan pengaruh yang baik bagi bangsa Indonesia kelak. Permasalahan seperti pornografi, bullying, tawuran, dan banyak lagi masih sering ditemukan pada remaja di daerah perkotaan maupun perdesaan. Ditegaskan dalam Profil Kriminalitas Remaja (BPS, 2010), tindakan kenakalan yang dilakukan remaja Indonesia berada pada kondisi yang memprihatinkan. Sebanyak 60,0 persen remaja Indonesia diketahui pernah melakukan tindak pencurian.

Selain itu, Pusat Data dan Informasi Kementerian Kesehatan RI (2014) menunjukkan bahwa dari tahun 2011 ke tahun 2012 jumlah pengguna narkoba usia di bawah 19 tahun naik dari 1.891 orang menjadi 2.238 orang. Laporan pihak kepolisian memperlihatkan bahwa kecenderungan tindakan kriminal yang dilakukan oleh remaja meningkat sebesar 4,3 persen setiap tahunnya. Masalah yang timbul pada remaja sangat erat kaitannya dengan kualitas karakter yang dimiliki.

Penelitian yang dilakukan oleh Dewanggi et al. (2015) menemukan bahwa kualitas karakter anak di perdesaan lebih rendah dibandingkan di wilayah perbatasan antara kota dan desa. Akan tetapi, penelitian tersebut dilakukan pada anak usia dini. Sementara itu, hasil penelitian Hastuti et al. (2013) memperlihatkan bahwa remaja Indonesia khususnya di Kota dan Kabupaten Bogor masih rentan terkena masalah yang berkaitan dengan karakter. Maka dari itu, penting untuk dilakukan penelitian 
tentang kualitas karakter remaja khususnya di wilayah perdesaan.

Adanya permasalahan seperti di atas menimbulkan pertanyaan mengenai peran orang tua dalam membentuk lingkungan pengasuhan yang kondusif bagi perkembangan karakter remaja. Oleh karena itu, penting untuk dilakukan penelitian tentang pengaruh kelekatan dan komunikasi remaja dengan orang tua terhadap karakter remaja di perdesaan. Tujuan dari penelitian ini adalah (1) mengidentifikasi karakteristik anak dan keluarga, kelekatan dengan orang tua, komunikasi dengan orang tua, dan kekuatan karakter; (2) mengidentifikasi hubungan kelekatan dan komunikasi remaja dengan orang tua terhadap kekuatan karakter; dan (3) menganalisis pengaruh karakteristik anak dan keluarga, kelekatan dan komunikasi remaja dengan orang tua terhadap kekuatan karakter.

\section{METODE}

Penelitian ini menggunakan desain penelitian cross sectional. Penelitian dilaksanakan di Desa Ciasihan dan Desa Ciasmara, Kecamatan Pamijahan, Kabupaten Bogor, Provinsi Jawa Barat. Lokasi penelitian dipilih secara purposive, dengan pertimbangan sebagai salah satu dari lima peringkat teratas daerah yang merepresentasikan usaha pertanian terbesar di Kabupaten Bogor. Lokasi penelitian ditentukan menggunakan metode purposive sampling dengan memilih satu Sekolah Menengah Kejuruan (SMK) di setiap desa. Pengambilan data dilaksanakan pada bulan April 2015 sampai dengan bulan Mei 2015. Penelitian ini adalah bagian dari penelitian Hibah Kompetensi Tahun 2015 dengan judul "Model Pengembangan Pendidikan Karakter Anak dan Keluarga Perdesaan Berbasis Family School Partnership".

Populasi penelitian ini adalah siswa yang memiliki orang tua lengkap dari sekolah yang terpilih di Desa Ciasihan dan Desa Ciasmara, Kecamatan Pamijahan, Kabupaten Bogor. Jumlah SMK yang ada di lokasi penelitian masing-masing sebanyak satu sekolah. Jumlah populasi dari penelitian ini sebanyak 287 siswa. Contoh dari penelitian ini adalah siswa kelas $X$ dan XI SMK dari sekolah yang terpilih sebagai lokasi penelitian. Penarikan contoh dilakukan dengan cara proportional random sampling berdasarkan jenis kelamin. Responden yang diambil dalam penelitian ini berjumlah 135 siswa untuk memperkecil terjadinya kesalahan saat penarikan responden. Setelah dilakukan pengambilan data terdapat 26 responden yang dikeluarkan dari daftar responden. Hal ini dikarenakan 10 responden tidak hadir pada saat pengambilan data, 9 responden orang tuanya tidak lengkap, serta sisanya telah keluar dari sekolah. Pada akhirnya data diperoleh dari 109 responden yang terdiri dari 44 remaja perempuan dan 65 remaja laki-laki dengan rata-rata usia 16 tahun. Pengumpulan data menggunakan teknik self-report dengan bantuan kuesioner. Data primer yang dikumpulkan meliputi karakteristik remaja (jenis kelamin dan usia), karakteristik keluarga (usia orang tua, lama pendidikan orang tua, pendapatan orang tua), komunikasi dengan orang tua, kelekatan dengan orang tua, serta karakter remaja yang terdiri dari pengetahuan moral (moral knowing), perasaan moral (moral feeling), dan tindakan moral (moral action).

Pengukuran kelekatan remaja dengan orang tua menggunakan pengembangan kuesioner dari Adolescent Attachment Questionnaire (West et al., 1998). Total pertanyaan untuk variabel kelekatan dengan orang tua adalah 17 pertanyaan dengan reliabilitas 0,692. Validitas dari instrumen pengukuran kelekatan dengan orang tua berkisar antara 0,189 sampai dengan 0,568 . Kelekatan dengan orang tua diukur dengan pertanyaan dengan contoh sebagai berikut. "Saya dapat mengandalkan orang tua saya kapan pun saya membutuhkan mereka." dan juga "Saya takut akan kehilangan cinta dari orang tua saya."

Pengukuran komunikasi remaja dengan orang tua menggunakan instrumen yang dikembangkan dari Parent-Adolescent Communication Scale (Barnes \& Olson, 1985). Kuesioner komunikasi dengan orang tua terdiri atas 19 pertanyaan dengan reliabilitas 0,803 dan nilai validitas berkisar antara 0,191 sampai dengan 0,680. Komunikasi antara remaja dengan orang tua terbagi menjadi dua dimensi yaitu, keterbukaan dalam berkomunikasi dan permasalahan dalam berkomunikasi. Contoh pertanyaan untuk dimensi keterbukaan dalam komunikasi adalah "Saya dapat membicarakan tentang apa yang saya percayai dengan orang tua saya tanpa merasa malu dan tertahan". Selanjutnya, salah satu contoh pertanyaan untuk dimensi permasalahan dalam komunikasi yaitu "Orang tua saya menghina saya ketika mereka marah kepada saya".

Pengukuran variabel karakter remaja menggunakan pengembangan dari kuesioner 
VIA-Youth dari Peterson dan Seligman (2004) yang dikembangkan menggunakan tiga dimensi dari Lickona (1994) yaitu moral knowing, feeling, dan action. Total pertanyaan untuk dimensi pengetahuan (knowing) berjumlah 21 pertanyaan dengan nilai reliabilitas sebesar 0,848 . Nilai validitas dari instrumen pengetahuan moral atau moral knowing adalah sebesar 0,394 sampai dengan 0,667.

Dimensi pengetahuan moral diukur dengan bentuk pertanyaan yang berkaitan dengan pengetahuan mereka terhadap nilai-nilai kebaikan. Contoh pertanyaan untuk dimensi moral adalah seperti "Kebersihan sekolah merupakan tanggung jawab seluruh warga sekolah" dan "Setiap orang harus selalu berhati-hati agar tidak terlibat dalam masalah". Selanjutnya, dimensi perasaan (feeling) berjumlah 22 pertanyaan dengan nilai reliabilitas 0,775 . Nilai validitas dari instrumen perasaan moral atau moral feeling adalah sebesar 0,291 sampai dengan 0,598. Dimensi perasaan moral diukur dengan bentuk pertanyaan yang berkaitan dengan perasaan mereka terhadap nilai-nilai kebaikan. Contohnya seperti "Saya merasa bertanggung jawab untuk menjaga kebersihan sekolah" dan "Saya merasa senang ketika saya dapat menyelesaikan masalah dan semua orang senang dengan solusi yang saya berikan".

Terakhir adalah dimensi tindakan (action) yang berjumlah 21 pertanyaan dengan nilai reliabilitas 0,705 . Nilai validitas dari instrumen tindakan moral atau moral acting adalah sebesar 0,190 sampai dengan 0,557 . Dimensi tindakan moral diukur dengan bentuk pertanyaan yang berkaitan dengan tindakan mereka yang berkaitan dengan nilai-nilai kebaikan contohnya seperti "Saya ikut kerja bakti untuk membersihkan sekolah." dan "Jika ada hal-hal baru yang menarik bagi saya, saya akan mencari tahu lebih banyak tentang hal tersebut."

Keseluruhan kuesioner menggunakan skala Likert 1-4 yang meliputi $S S=$ Sangat Sesuai; $\mathrm{S}=$ Sesuai; $\mathrm{TS}=$ Tidak Sesuai; dan STS= Sangat Tidak Sesuai. Setelah data terkumpul, sistem scoring yang dilakukan untuk variabel komunikasi dengan orang tua, kelekatan dengan orang tua, dan karakter menggunakan rumus indeks. Data pendapatan orang tua dikonversikan menjadi pendapatan per kapita yang kemudian dikategorikan menggunakan indikator garis kemiskinan BPS Kabupaten Bogor tahun 2013. Pengategorian variabel kelekatan dengan orang tua, komunikasi dengan orang tua, dan karakter remaja dibagi menjadi tinggi dan rendah. Pengategorian indeks masing-masing variabel menggunakan standar nilai normatif dengan cut off point baik/tinggi $(80,0-100,0)$ dan kurang/rendah $(0,0-$ $80,0)$. Penetapan standar menggunakan ukuran normatif pada variabel kelekatan, komunikasi, serta karakter remaja diharapkan dapat menggambarkan kualitas variabel dengan lebih baik.

Analisis deskriptif yang dilakukan adalah nilai minimal, nilai maksimal, rata-rata, standar deviasi, serta frekuensi. Analisis inferensial yang digunakan untuk menjawab tujuan penelitian adalah uji korelasi dan uji regresi. Uji korelasi dilakukan untuk mengetahui hubungan antar variabel penelitian. Uji regresi digunakan untuk mengetahui pengaruh karakteristik remaja dan keluarga, kelekatan remaja dengan orang tua, komunikasi remaja dengan orang tua terhadap karakter remaja.

\section{HASIL}

\section{Karakteristik Remaja dan Keluarga}

Usia remaja yang menjadi responden dalam penelitian ini berkisar antara 15 tahun sampai dengan 19 tahun. Usia tersebut dikatakan berada pada tahapan remaja akhir. Rata-rata usia ayah dan usia ibu berada pada kategori dewasa madya yaitu 47 tahun, dengan rentang usia mulai dari 30 sampai dengan 75 tahun. Selanjutnya, lama pendidikan ayah dan pendidikan ibu tergolong rendah dengan ratarata keduanya selama lima tahun. Hal tersebut menunjukkan bahwa rata-rata pendidikan orang tua tidak lulus Sekolah Dasar (SD). Tahun 2013 standar garis kemiskinan Kabupaten Bogor meningkat dari tahun 2011 yaitu dari Rp235.682,00 menjadi Rp271.970,00. Setengah dari total keseluruhan responden $(52,3 \%)$ masih tergolong keluarga miskin. Temuan ini menunjukkan bahwa keluarga perdesaan dalam penelitian ini mempunyai status sosial ekonomi rendah.

\section{Kelekatan dan Komunikasi Remaja dengan Orang Tua}

Tabel 1 menunjukkan bahwa skor kelekatan remaja dengan orang tua berkisar antara 29,41 sampai dengan 86,27 . Rata-rata skor kelekatan remaja dengan orang tua didapatkan sebesar 63,75 dengan standar deviasi sebesar $\pm 10,30$. Dilihat dari nilai rata-rata kelekatan 
remaja dengan orang tuanya, hasil ini menunjukkan bahwa di keluarga perdesaan yang memiliki anak remaja, rata-rata kelekatannya tergolong kurang.

Hasil penelitian ini menunjukkan bahwa hampir seluruh remaja $(93,6 \%)$ yang menjadi responden dalam penelitian ini masih memiliki skor kelekatan dengan orang tua yang rendah (Tabel 2). Kelekatan yang rendah antara remaja dan orang tua tergambar dari hasil analisis pertanyaan. Hasil menunjukkan bahwa lebih dari setengah responden $(76,2 \%)$ merasa bahwa orang tua mereka hanya memberikan perhatian saat mereka sedang marah saja. Selain itu, kaum remaja juga merasa orang tua mereka tidak ada pada saat mereka tertimpa masalah. Kurangnya waktu bersama antara remaja dan orang tua membuat remaja merasa kecewa. Masih ada remaja yang merasa takut akan kehilangan cinta dari orang tuanya. Sebanyak 80,0 persen dari total responden sering merasa marah kepada orang tua mereka tanpa sebab. Hal-hal seperti di atas membuat remaja tidak memiliki kepercayaan dan rasa aman akan hubungannya dengan orang tuanya.

Sementara itu, komunikasi remaja dan orang tua dalam penelitian ini diukur berdasarkan dua dimensi, yaitu dimensi keterbukaan dan permasalahan komunikasi. Hasil penelitian menunjukkan bahwa hampir seluruh remaja $(95,4 \%)$ masih berada pada kategori rendah untuk variabel komunikasi dengan orang tua (Tabel 2). Rata-rata skor komunikasi remaja dan orang tua didapatkan sebesar 62,0 persen dengan rentang skor 15,79 sampai dengan 89,47 (Tabel 1). Nilai rata-rata menunjukkan masih belum terbangunnya komunikasi yang positif antara orang tua dengan anak remajanya di perdesaan.

Selanjutnya, hasil pada Tabel 2 menunjukkan bahwa komunikasi yang rendah antara remaja dan orang tua dikarenakan hanya sedikit remaja yang terbuka saat berkomunikasi dengan orang tua. Remaja masih terlalu berhati-hati dalam berkomunikasi dengan orang tua serta masih ada yang merasa tidak nyaman menyampaikan perasaannya kepada orang tua.

Tabel 1 Sebaran skor minimum, maksimum, rata-rata dan standar deviasi kelekatan dan komunikasi dengan orang tua

\begin{tabular}{lcc}
\hline \multicolumn{1}{c}{ Variabel } & $\begin{array}{c}\text { Minimum }- \\
\text { maksimum }\end{array}$ & $\begin{array}{c}\text { Rata-rata } \pm \\
\text { standar } \\
\text { deviasi }\end{array}$ \\
\hline $\begin{array}{l}\text { Kelekatan } \\
\text { dengan orang tua }\end{array}$ & $29,41-86,27$ & $63,75 \pm 10,30$ \\
$\begin{array}{l}\text { Komunikasi } \\
\text { dengan orang tua }\end{array}$ & $15,79-89,47$ & $62,02 \pm 11,43$ \\
\hline
\end{tabular}

Tabel 2 Sebaran remaja berdasarkan kategori kelekatan dan komunikasi dengan orang tua

\begin{tabular}{lcc}
\hline \multicolumn{1}{c}{ Kategori Variabel } & $\mathrm{n}$ & $\%$ \\
\hline Kelekatan dengan orangtua & & \\
Rendah & 102 & 93,6 \\
Tinggi & 7 & 6,4 \\
\hline Keterbukaan komunikasi & & \\
$\quad$ Rendah & 94 & 86,2 \\
$\quad$ Tinggi & 15 & 13,8 \\
\hline Permasalahan komunikasi & & \\
$\quad$ Rendah & 6 & 5,5 \\
$\quad$ Tinggi & 103 & 94,5 \\
\hline Komunikasi total & & \\
$\quad$ Rendah & 104 & 95,4 \\
Tinggi & 5 & 4,6 \\
\hline
\end{tabular}

Sebanyak 86,2 persen remaja masih memiliki kategori keterbukaan dalam berkomunikasi yang rendah. Keterbukaan yang rendah tergambar dari rasa takut untuk mengungkapkan perasaan yang sebenarnya pada orang tua dan membicarakan permasalahan yang sedang dialami.

Keterbukaan yang rendah juga membuat remaja takut mengatakan hal yang ia inginkan kepada orang tuanya. Selain keterbukaan dalam berkomunikasi yang rendah, hampir seluruh responden $(94,5 \%)$ memiliki tingkat permasalahan dalam berkomunikasi yang tinggi dengan orang tua (Tabel 2). Hal tersebut menunjukkan bahwa pada penelitian ini masih sering terjadi permasalahan antara remaja dengan orang tua dalam berkomunikasi. Temuan dalam penelitian ini mengindikasikan bahwa pengetahuan dan keterampilan orang tua di perdesaan dalam membangun komunikasi yang terbuka dengan anak remajanya belum mencukupi.

Sebanyak 85,3 persen remaja yang menjadi responden dalam penelitian ini menyatakan bahwa mereka pernah dihina oleh orang tua apabila orang tua mereka sedang marah. Orang tua juga masih sering mengatakan halhal yang sebaiknya tidak dikatakan pada anak mereka. Saat remaja memiliki masalah dengan orang tuanya, remaja memilih untuk mendiamkan daripada menyelesaikannya. Selain itu, para remaja juga merasa terganggu oleh orang tua mereka.

\section{Karakter Remaja}

Dimensi karakter remaja dalam penelitian ini dinilai dalam aspek pengetahuan moral (moral knowing), perasaan moral (moral feeling), tindakan moral (moral action), serta karakter secara keseluruhan. 
Tabel 3 Sebaran remaja berdasarkan kategori karakter

\begin{tabular}{lcc}
\hline \multicolumn{1}{c}{ Kategori Variabel } & $\mathrm{n}$ & $\%$ \\
\hline Pengetahuan moral & & \\
$\quad$ Rendah & 36 & 33,0 \\
$\quad$ Tinggi & 73 & 67,0 \\
Perasaan moral & & \\
$\quad$ Rendah & 84 & 77,1 \\
$\quad$ Tinggi & 25 & 22,9 \\
Tindakan moral & & \\
$\quad$ Rendah & 104 & 95,4 \\
$\quad$ Tinggi & 5 & 4,6 \\
Karakter Total & & \\
$\quad$ Rendah & 91 & 83,5 \\
$\quad$ Tinggi & 18 & 16,5 \\
\hline
\end{tabular}

Rata-rata responden berada pada kategori tinggi dalam dimensi pengetahuan (rata-rata skor 84,48 ). Sebaliknya, skor rata-rata pada dimensi tindakan moral yang dilakukan remaja hanya sebesar 64,74 atau hampir seluruh responden $(95,4 \%)$ berada pada kategori rendah. Hasil tersebut memperlihatkan bahwa remaja mengetahui mana tindakan yang baik atau buruk, namun belum tentu remaja tidak melakukan tindakan yang buruk. Hasil analisis karakter remaja dimensi perasaan moral menunjukkan bahwa sebanyak lebih dari tiga perempat remaja $(77,1 \%)$ termasuk kategori rendah (Tabel 3). Rendahnya perasaan moral dan tindakan moral ditunjukkan dari hasil penelitian yang memperlihatkan bahwa hampir seluruh remaja $(91,7 \%)$ menyatakan bahwa kebersihan sekolah merupakan tanggung jawab seluruh warga sekolah. Pada kenyataannya sebanyak 61,5 persen dari total responden menyatakan tidak ikut apabila diadakan kerja bakti di sekolah. Rata-rata skor karakter secara keseluruhan hanya 73,93 atau belum dapat dikatakan baik karena hanya 16,5 persen remaja yang berada pada kategori karakter baik.

\section{Variabel Bebas yang Berhubungan dengan Karakter Remaja}

Hasil penelitian pada Tabel 4 menunjukkan bahwa jenis kelamin berhubungan signifikan negatif dengan seluruh dimensi karakter remaja. Penelitian menemukan bahwa remaja perempuan memiliki skor yang lebih baik pada setiap dimensi karakter dibandingkan dengan remaja laki-laki.

Hasil penelitian seperti yang tersaji pada Tabel 4 menunjukkan bahwa usia remaja berhubungan signifikan negatif dengan pengetahuan moral. Pada penelitian ini, remaja yang berusia lebih muda memiliki skor pengetahuan moral yang lebih tinggi dibandingkan dengan remaja yang lebih tua.
Tabel 4 Koefisien korelasi antara karakteristik remaja, keluarga, kelekatan serta komunikasi remaja dan orang tua dengan karakter remaja.

\begin{tabular}{|c|c|c|c|c|}
\hline \multirow[b]{2}{*}{ Variabel } & \multicolumn{4}{|c|}{ Koefisien korelasi } \\
\hline & $\begin{array}{l}\text { Penge- } \\
\text { tahuan } \\
\text { moral }\end{array}$ & $\begin{array}{c}\text { Perasa- } \\
\text { an } \\
\text { moral }\end{array}$ & $\begin{array}{l}\text { Tindak- } \\
\text { an } \\
\text { moral }\end{array}$ & $\begin{array}{c}\text { Karak- } \\
\text { ter } \\
\text { Total }\end{array}$ \\
\hline $\begin{array}{l}\text { Jenis } \\
\text { kelamin } \\
\text { ( } 0=\text { =erem- } \\
\text { puan, } \\
1=\text { laki-laki) }\end{array}$ & $-0,265^{\star *}$ & $-0,228^{*}$ & $-0,246^{* \star}$ & $-0,289^{\star \star}$ \\
\hline $\begin{array}{l}\text { Usia remaja } \\
\text { (tahun) }\end{array}$ & $-0,193^{\star}$ & $-0,087$ & $-0,124$ & $-0,1$ \\
\hline $\begin{array}{l}\text { Usia ibu } \\
\text { (tahun) }\end{array}$ & 0,062 & $0,192^{*}$ & $-0,066$ & 0,0 \\
\hline $\begin{array}{l}\text { Lama } \\
\text { pendidikan } \\
\text { ayah } \\
\text { (tahun) }\end{array}$ & 0,067 & $-0,014$ & 0,076 & 0,0 \\
\hline $\begin{array}{l}\text { Lama } \\
\text { pendidikan } \\
\text { ibu (tahun) }\end{array}$ & 0,109 & 0,042 & 0,131 & 0,1 \\
\hline $\begin{array}{l}\text { Pendapatan } \\
\text { per kapita } \\
\text { (rupiah) }\end{array}$ & $-0,088$ & $-0,117$ & 0,058 & $-0,0$ \\
\hline $\begin{array}{l}\text { Kelekatan } \\
\text { orang tua } \\
\text { (skor) }\end{array}$ & $0,204^{\star}$ & 0,138 & 0,138 & $0,1 \varepsilon$ \\
\hline $\begin{array}{l}\text { Komunikasi } \\
\text { orang tua } \\
\text { (skor) }\end{array}$ & 0,185 & $0,232^{\star}$ & $0,249^{\star *}$ & 0,263 \\
\hline
\end{tabular}

Hasil penelitian juga menemukan bahwa usia ibu berhubungan signifikan positif dengan perasaan moral remaja. Remaja yang memiliki ibu dengan usia yang lebih tua memiliki skor perasaan moral yang lebih baik dibandingkan remaja dengan ibu yang usianya lebih muda.

Hasil lain juga menemukan bahwa kelekatan remaja dengan orangtua juga berhubungan signifikan dan positif dengan pengetahuan moral. Komunikasi remaja dengan orang tua ditemukan berhubungan signifikan positif dengan perasaan moral, tindakan moral, serta karakter remaja secara keseluruhan. Artinya, apabila komunikasi yang terjalin antara remaja dan orang tua saling terbuka serta terhindar dari masalah, maka skor perasaan, tindakan moral, dan karakter keseluruhan remaja semakin baik.

\section{Variabel Bebas yang yang Memengaruhi Karakter Remaja}

Hasil penelitian menunjukkan bahwa jenis kelamin remaja berpengaruh terhadap seluruh dimensi karakternya. Remaja perempuan 
ditemukan memiliki skor karakter yang lebih baik dibandingkan dengan remaja laki-laki, baik pada dimensi pengetahuan moral, perasaan moral, tindakan moral dan karakter total. Usia ibu juga ditemukan memengaruhi perasaan moral remaja secara positif. Hasil ini menunjukkan bahwa penambahan usia ibu, maka akan meningkatkan perasaan moral remaja lebih baik.

Kelekatan remaja dan orang tua tidak berpengaruh secara signifikan terhadap karakter remaja. Sebaliknya, komunikasi remaja dengan orang tua ditemukan berpengaruh positif terhadap perasaan moral, tindakan moral, serta karakter remaja secara keseluruhan. Model penelitian ini dapat menjelaskan pengaruhnya terhadap karakter remaja sebesar 13,4 persen. Sisanya, sebanyak 86,6 persen dijelaksan oleh variabelvariabel lain yang tidak diteliti.

\section{PEMBAHASAN}

Identitas moral atau karakter seseorang merupakan hasil dari sebuah proses yang terjadi sepanjang masa perkembangan individu. Menurut Lickona (1994), agar karakter seseorang dapat berkembang dengan optimal, diperlukan pengasuhan efektif yang dilakukan oleh orang tua. Hal ini menegaskan peran pentingnya keluarga dalam membentuk karakter anak, yang terus berlanjut mulai dari usia kanak-kanak hingga remaja. Penelitian ini mengangkat kelekatan dan komunikasi sebagai aspek pengasuhan yang diduga memengaruhi karakter remaja. Tujuan pertama penelitian ini adalah mengidentifikasi komunikasi dan kelekatan remaja dengan orang tua. Hasil penelitian menunjukkan bahwa kelekatan yang dimiliki orang tua dan remaja di perdesaan masih berada pada kategori rendah.
Kebanyakan remaja merasa dikecewakan dan kurang diperhatikan oleh orang tua mereka. Perasaan kecewa dan rasa kurang diperhatikan oleh orang tua dapat berdampak pada komunikasi yang terjalin antara remaja dengan orang tuanya. Hal tersebut tergambar dari tingginya skor permasalahan komunikasi remaja dengan orang tuanya. Tidak sedikit responden yang pernah dihina oleh orang tuanya ketika orang tuanya sedang marah.

Selain itu, keterbukaan dalam berkomunikasi antara orang tua dan remaja juga masih rendah. Remaja cenderung berhati-hati dalam menyampaikan sesuatu kepada orang tuanya. Hasil penelitian ini sejalan dengan penelitian Meeus et al. (2002) yang menemukan adanya hubungan antara kelekatan orang tua dan remaja dengan cara mereka berkomunikasi.

Kelekatan dan komunikasi yang tidak berjalan baik antara remaja dan orang tua bisa dipengaruhi oleh kondisi sosial ekonomi keluarga. Rendahnya tingkat pendidikan orang tua serta banyaknya responden yang berasal dari keluarga miskin menjadi faktor yang membuat kelekatan dan komunikasi tidak berjalan dengan baik. Banyak hal yang dapat memengaruhi kemampuan berkomunikasi antara orang tua dan remaja. Salah satu faktor yang dapat memengaruhi komunikasi dalam keluarga adalah kondisi ekonomi keluarga.

Hasil penelitian menunjukkan bahwa responden pada penelitian ini lebih dari setengahnya berasal dari keluarga miskin. Malin et al. (2013) menemukan bahwa tingkat sosial ekonomi keluarga yang rendah akan memengaruhi kemampuan berkomunikasi anak dan orang tua. Selain itu, pendidikan orang tua baik ayah maupun ibu juga dapat memengaruhi kelekatan yang terjadi antara orang tua dan anak.

Tabel 5 Hasil analisis regresi linier berganda variabel-variabel yang memengaruhi karakter remaja

\begin{tabular}{|c|c|c|c|c|c|c|c|c|}
\hline \multirow[t]{2}{*}{ Variabel } & \multicolumn{2}{|c|}{$\begin{array}{l}\text { Pengetahuan } \\
\text { Moral }\end{array}$} & \multicolumn{2}{|c|}{ Perasaan Moral } & \multicolumn{2}{|c|}{ Tindakan Moral } & \multicolumn{2}{|c|}{ Karakter Total } \\
\hline & $\mathrm{B}$ & Sig. & B & Sig. & B & Sig. & $\mathrm{B}$ & Sig. \\
\hline Konstanta & 96,032 & 0,000 & 67,515 & 0,000 & 63,299 & 0,002 & 75,615 & 0,000 \\
\hline $\begin{array}{l}\text { Jenis kelamin }(0=\text { perempuan, } \\
1=\text { laki-laki) }\end{array}$ & $-4,471$ & $0,009 * *$ & $-4,631$ & $0,010^{\star *}$ & $-5,028$ & $0,011^{*}$ & $-4,710$ & $0,002^{* *}$ \\
\hline Usia remaja (tahun) & $-1,317$ & 0,181 & $-0,583$ & 0,572 & $-0,170$ & 0,882 & $-0,690$ & 0,431 \\
\hline Usia ibu (tahun) & 0,111 & 0,295 & 0,244 & $0,030^{*}$ & $-0,074$ & 0,549 & 0094 & 0,321 \\
\hline Lama pendidikan ayah (tahun) & 0,079 & 0,853 & $-0,208$ & 0,642 & $-0,221$ & 0,654 & $-0,117$ & 0,758 \\
\hline Lama pendidikan ibu (tahun) & 0,215 & 0,643 & 0,267 & 0,585 & 0,442 & 0,413 & 0,308 & 0,458 \\
\hline $\begin{array}{l}\text { Pendapatan per kapita } \\
\text { (rupiah) }\end{array}$ & $\begin{array}{c}-3.419 \mathrm{E}- \\
6\end{array}$ & 0,079 & $\begin{array}{c}-3.733 \mathrm{E}- \\
6\end{array}$ & 0,065 & $\begin{array}{c}2.623 \mathrm{E}- \\
7\end{array}$ & 0,907 & $\begin{array}{c}-2.310 \mathrm{E}- \\
6\end{array}$ & 0,182 \\
\hline Kelekatan orang tua (skor) & 0,112 & 0,197 & 0,026 & 0,755 & 0,007 & 0,943 & 0,049 & 0,531 \\
\hline Komunikasi orang tua (skor) & 0,094 & 0,227 & 0,188 & $0,022^{*}$ & 0,221 & $0,015^{\star}$ & 0,168 & $0,016^{*}$ \\
\hline Adjusted R Square & \multicolumn{2}{|c|}{0,108} & \multicolumn{2}{|c|}{0,121} & \multicolumn{2}{|c|}{0,076} & \multicolumn{2}{|c|}{0,134} \\
\hline
\end{tabular}


Hasil penelitian sebelumnya yang telah dilakukan oleh Davis-Kean (2005) dan AlMatalka (2014) menyatakan bahwa orang tua yang memiliki pendidikan tinggi memiliki keterlibatan yang tinggi dan menyediakan lingkungan yang nyaman serta hangat bagi proses pengasuhan anak. Diduga pada penelitian ini rendahnya pendidikan orang tua membuat proses pengasuhan tidak berjalan dengan baik. Selain itu, rendahnya keterlibatan orang tua membuat remaja memiliki kelekatan yang tidak baik dengan orang tuanya.

Tujuan lain dari penelitian ini adalah mengidentifikasi karakter remaja di perdesaan. Hasil penelitian memperlihatkan bahwa dari ketiga komponen moral yang diteliti baik pengetahuan, perasaan, maupun tindakan moral terdapat perbedaan skor pada setiap dimensinya. Pengetahuan moral remaja memiliki rata-rata skor yang lebih tinggi dibandingkan dua dimensi lainnya dan skor karakter secara keseluruhan. Hal tersebut memperlihatkan bahwa pengetahuan yang baik belum tentu mendorong seseorang untuk melakukan hal yang baik pula. Hasil analisis butir pertanyaan memperlihatkan bahwa hampir seluruh responden mengetahui bahwa kebersihan sekolah merupakan tanggung jawab seluruh warga sekolah, akan tetapi pada kenyataannya hampir seluruh responden juga mengatakan bahwa mereka tidak pernah membersihkan sekolah. Pengetahuan yang dimiliki remaja tentang sesuatu yang baik dan benar tidak menjamin ia melakukan hal tersebut. Selain itu, banyak hal yang dapat memengaruhi tindakan seorang remaja misalnya pengaruh lingkungan sekitar. Remaja memiliki kecenderungan untuk melakukan hal yang tidak baik apabila lingkungan di sekitarnya terbiasa melakukan hal yang tidak baik juga (Hair et al., 2002). Secara keseluruhan skor karakter remaja perdesaan masih berada pada kategori kurang.

Hasil uji korelasi dan regresi memperlihatkan bahwa skor setiap dimensi moral serta karakter secara keseluruhan dipengaruhi oleh jenis kelamin remaja. Penelitian ini menunjukkan bahwa skor seluruh dimensi karakter remaja perempuan lebih baik dibandingkan skor remaja laki-laki. Temuan ini sejalan dengan hasil penelitian Karina et al., (2013) yang menemukan bahwa remaja perempuan memiliki skor karakter yang lebih baik dibandingkan dengan remaja laki-laki. Akan tetapi, perkembangan karakter seseorang tidak mutlak ditentukan oleh jenis kelaminnya karena setiap orang akan melewati tahapan perkembangan moral yang sama.
Usia remaja memiliki hubungan negatif dengan pengetahuan moralnya. Pada penelitian ini, remaja yang berusia lebih muda memiliki skor pengetahuan moral lebih baik. Temuan ini bertentangan dengan hasil penelitian Dewanggi et al. (2015) yang melakukan penelitian pada anak usia prasekolah/usia dini menemukan bahwa semakin tinggi usia maka seharusnya semakin baik pula karakter yang dimilikinya. Selain itu, usia ibu juga ditemukan memiliki hubungan dan pengaruh positif terhadap perasaan moral remaja. Usia ibu yang semakin matang membuat pengasuhan yang dilakukannya semakin baik. Lingkungan pengasuhan yang baik akan memberi dampak pada perkembangan karakter seseorang (Dewanggi et al., 2015).

Penelitian ini menemukan remaja yang memiliki kelekatan positif dengan orang tua akan memiliki pengetahuan moral yang baik. Hal tersebut terlihat dari hasil uji hubungan yang menunjukkan adanya hubungan positif antara kelekatan remaja dan orang tua dengan pengetahuan moral remaja. Temuan ini sejalan dengan hasil penelitian dari Thomas (2011) yang menemukan bahwa kelekatan yang positif antara remaja dan orang tua akan memengaruhi nilai moral remaja.

Hasil lainnya menunjukkan bahwa terdapat hubungan antara komunikasi remaja dan orang tua dengan karakter secara keseluruhan kecuali dimensi pengetahuan. Temuan tersebut dikuatkan oleh hasil penelitian De Guzman \& Carlo (2004) yang menyatakan bahwa komunikasi yang berjalan baik antara orang tua dan remaja akan memberikan dampak terhadap perkembangan remaja salah satunya identitas moral atau karakter. Lingkungan pengasuhan yang penuh cinta dapat menjadi dasar terjalinnya kelekatan dan komunikasi positif antara orang tua dengan remaja. Dengan demikian, identitas moral dan karakter remaja dapat terbentuk dengan baik (Lickona, 1994). Akan tetapi, pada penelitian ini membuktikan bahwanya rasa tidak saling percaya serta komunikasi yang buruk antara orang tua dan remaja membuat identitas moral dan karakter remaja tidak terbentuk dengan baik.

Kelekatan merupakan proses panjang semenjak anak masih berada di dalam kandungan sampai dengan dewasa. Kelekatan yang terbentuk pada saat awal kehidupan akan cenderung tetap sampai seseorang beranjak dewasa. Kelekatan antara remaja dan orang tua ditemukan tidak berpengaruh terhadap karakter remaja. Berdasarkan hasil penelitian dari Van Ijzendoorn \& Zwart-Woudstra (1995), 
kelekatan yang aman dengan orang tua seharusnya memengaruhi kemampuan moral reasoning seseorang. Berbeda dari penelitianpenelitian sebelumnya, kelekatan dengan orang tua ditemukan tidak memengaruhi karakter remaja dalam penelitian ini. Hal tersebut dapat disebabkan oleh berbagai macam hal. Fase remaja sendiri ditandai dengan kemandirian dan kemampuan berpikir yang semakin meningkat. Kemandirian yang semakin meningkat membuat kelekatan dengan orang tua saja tidak cukup kuat dalam memengaruhi karakter remaja.

Pada remaja, proses komunikasi di dalam keluarga merupakan hal yang penting untuk dilakukan. Kemampuan berpikir yang semakin meningkat membuat nilai-nilai karakter lebih mudah ditransmisikan melalui proses diskusi (Louis \& Emerson, 2011). Proses komunikasi yang hangat dan penuh cinta sangat diperlukan untuk mengawal perkembangan seorang remaja. Komunikasi yang terhindar dari masalah serta terbuka antara remaja dan orang tua dapat meningkatkan perasaan moral, tindakan moral, serta karakter remaja menjadi lebih baik. Hal tersebut terlihat dengan adanya pengaruh antara komunikasi remaja dengan orang tua terhadap karakter remaja. Perkembangan seorang remaja tidak lepas dari proses interaksi yang terjadi antara dirinya dan lingkungan disekelilingnya.

Menurut Davidson \& Cardemil (2009), hubungan antara remaja dan orang tua dibangun berdasarkan dua aspek penting yaitu komunikasi antara remaja dan orang tua serta keterlibatan orang tua. Komunikasi yang baik juga terbukti berhubungan dengan kesejahteraan serta perkembangan diri remaja. Menurut Moitra \& Mukherjee (2009) kepuasan dalam berkomunikasi antara orang tua dan remaja merupakan faktor penting dalam menghindari perilaku bermasalah pada remaja. Selain itu, proses komunikasi ataupun diskusi yang dilakukan orang tua dengan remaja dapat membantu mengembangkan kemampuan moral reasoning remaja tersebut (Stanley, 1978).

Pada penelitian ini, tingginya permasalahan komunikasi antara orang tua dan remaja berdampak pada kemampuan moral reasoning serta karakter remaja. Keterbatasan dari penelitian ini adalah komunikasi dan kelekatan dengan orang tua diukur berdasarkan kepada persepsi anak terhadap hubungannya dengan orang tua. Selain itu, pengukuran kelekatan orang tua dengan remaja tidak dipisahkan antara kelekatan dengan ibu ataupun ayah.

\section{SIMPULAN DAN SARAN}

Hasil penelitian ini menemukan bahwa kelekatan antara remaja dan orang tua tergolong rendah. Selain itu, komunikasi antara orang tua juga masih tergolong rendah. Remaja memiliki permasalahan komunikasi yang tinggi dengan orang tua. Selain itu, keterbukaan dalam berkomunikasi masih rendah. Pengetahuan moral remaja ditemukan sudah cukup baik. Hal yang berbeda terlihat pada skor perasaan moral, tindakan moral, maupun karakter remaja yang ditemukan masih terkategori rendah. Usia remaja berhubungan negatif dengan pengetahuan moralnya. Sebaliknya, usia ibu ditemuikan berhubungan positif dengan perasaan moral remaja. Jenis kelamin remaja ditemukan berpengaruh terhadap seluruh dimensi karakternya. Remaja perempuan memiliki skor karakter yang lebih baik dibandingkan remaja laki-laki. Kelekatan antara remaja dan orang tua berhubungan negatif dengan pengetahuan moral. Perasaan moral, tindakan moral, serta karakter remaja dipengaruhi oleh komunikasi antara remaja dan orang tua. Permasalahan yang tinggi dalam berkomunikasi dan kurangnya keterbukaan dalam berkomunikasi membuat kekuatan karakter remaja menjadi rendah.

Hasil penelitian ini dapat dijadikan acuan bagi lembaga yang berkepentingan untuk membuat rencana strategis yang berkaitan dengan peningkatan kesejahteraan keluarga dan juga penanggulangan masalah kenakalan remaja di Indonesia. Diharapkan para lembaga terkait bisa memberikan pendampingan dan penyuluhan bagi keluarga di perdesaan mengenai lingkungan keluarga yang positif. Penyuluhan dapat dilakukan untuk memberikan informasi kepada orang tua tentang pentingnya kelekatan dan komunikasi efektif dalam mengasuh remaja. Mengingat rendahnya kualitas kelekatan remaja dengan orang tua maka orang tua perlu mendapatkan informasi mengenai pentingnya kelekatan dan bagaimana cara membangun kelekatan yang baik. Pendampingan keluarga dengan anak remaja di perdesaan juga dapat dilakukan dengan tujuan agar orang tua dapat meningkatkan kualitas hubungan dengan anak serta mengurangi permasalahan antara orang tua dan remaja di perdesaan. Orang tua dapat meningkatkan kualitas kelekatan dengan cara memberikan waktu dan perhatian yang lebih terhadap para remaja.

Penyuluhan mengenai komunikasi efektif dengan anak remaja juga dapat dilakukan dengan memberikan informasi mengenai 
bagaimana cara berkomunikasi dengan remaja. Mengingat keterbukaan remaja dengan orang tua yang rendah, orang tua diharapkan dapat mendorong anak untuk lebih terbuka dalam menyampaikan perasaannya. Hal tersebut dapat dilakukan dengan cara membiasakan anak untuk menceritakan apa yang terjadi pada dirinya. Selain itu, orang tua juga disarankan untuk menjadi pendengar yang baik bagi remaja dan membuat remaja nyaman dalam berkomunikasi. Terbentuknya kelekatan dan komunikasi yang efektif antara orang tua dan remaja diharapkan dapat membantu remaja di perdesaan agar memiliki karakter yang lebih baik.

\section{DAFTAR PUSTAKA}

Al-Matalka, F. I. M. (2014). The influence of parental socioeconomic status on their involvement at home. International Journal of Humanities and Social Science, 4(5).

Barnes, H. L., \& Olson, D. H. (1985). Parentadolescent communication and the circumplex model. Journal of Child Development, 56.

Berns, R. M. (2011). Child, family, school, community: Socialization and support. USA: Cengange Learning.

Blake, S. M., Simkin, L., Ledsky, R., Perkins, C. \& Calabrese, J. M. (2001). Effect of a parent-child communications intervention on young adolescents' risk for early onset of sexual intercourse. Journal of Family Planning Perspectives, 33(2).

[BPS] Badan Pusat Statistik. (2010). Profil kriminalitas remaja. Jakarta, ID: Badan Pusat Statistik.

Brdar, I., \& Kashdan, T. B. (2010). Character strengths and well-being in Croatia: An empirical investigation of structure and correlates. Journal of Research in Personality, 44, 151-154.

Davidson, T. M., \& Cardemil, E. V. (2009). Parent-child communication and parental involvement in latino adolescents. Journal of Early Adolescence, 29(1).

Davis-Kean, P. E. (2005). The influence of parent education and family income on child achievement: The indirect role of parental expectations and the home environment. Journal of Family Psychology, 19(2).

De Guzman, M. R. T., \& Carlo, G. (2004). Family, peer, and acculturtive correlates of prosocial development among latinos. Great Plains Research, 14.

Dewanggi, M., Hastuti, D., \& Herawati, T. (2015). The influence of attachment and quality of parenting and parenting environment on children's character in rural and urban areas of Bogor. Jurnal IImu Keluarga dan Konsumen, 8(1), 2027.

Hair, E. C., Jager, J., \& Garrett, S. B. (2002). Helping teens develop healthy social skills and relationships: What the research shows about navigating adolescence. Child Trends Research Brief.

Hastuti, D., Agung, S. S., \& Alfiasari. (2013). Kajian karakteristik remaja desa-kota, sekolah serta keluarga untuk mengatasi perilaku anti-sosial remaja SMK di Kota dan Kabupaten Bogor. Prosiding Seminar Hasil-Hasil PPM IPB II. 653-667.

Karina, Hastuti, D., \& Alfiasari. (2013). Perilaku bullying dan karakter remaja serta kaitannya dengan karakteristik keluarga dan peer group. Jural IImu Keluarga dan Konsumen, 6(1).

Keijsers, L., Branje, S. J. T., VanderValk, I. E., \& Meeus, W. (2010). Reciprocal effects between parental solicitation, parental control, adolescent disclosure, and adolescent delinquency. Journal of Research on Adolescence, 20(1), 88-113. doi: 10.1111/j.1532-7795.2009.00631.x.

Lai Kwok, S. Y. E., \& Shek, D. T. L. (2010). Hopelessness, parent-adolescent communication, and suicidal ideation among Chinese adolescents in Hong Kong. Suicide and Life-Threatening Behavior, 40(3).

Lickona, T. (1994). Raising Good Children. Amerika, US: Bantam Books.

Lickona, T. (2004). Why Character Matters. New York: Tounchstone

Louis, P. T., \& Emerson, I. A. (2011). A qualitative analysis on the moral judgement of high school students. Education Science and Psychology, 2(19). ISSN 1512-1801.

Malin, J. L., Karberg, E., Cabrera, N. J., Rowe, M., Cristaforo, T., \& Tamis-LeMonda, C. S. (2013). Father-toddler communication in low-income families: The role of paternal education and depressive symptoms. Journal of Family Science. doi:10. 1080/19424620.2012.779423. 
Meeus, W., Oosterwegel, A., \& Vollebergh, W. (2002). Parental and peer attachment and identity development in adolescence. Journal of Adolescence, 25.

Moitra, T., \& Mukherjee, I. (2009). Parentadolescent communication and delinquency: A comparative study in Kolkata, India. Europe's Journal of Psychology, 8(1).

Oladipo, S.E. (2009). Moral education of the child: Whose responsibility?. Journal Social Science, 20(2).

Peterson, C., \& Seligman, M. E. P. (2004). Character strengths and virtues: $A$ handbook and classification. New York, US: Oxford Univrsity Press.

Pusat data dan informasi Kementerian Kesehatan RI. (2014). Say no to drugs: Say yes to life. Diambil dari http:// www.depkes.go.id/resources/download/p usdatin/infodatin/infodatin-antinarkoba. pdf.

Selby, J. C. (2000). The relationship of parental attachment, peer attachment, and selfconcept to the adjustment of first-year college students (Disertasi). University of North Texas, Texas.

Shoshani, A., \& Slone, M. (2012). Middle school transition from the strengths perspective: Young adolescents' character strengths, subjective well-being, and school adjustment. Juornal Happiness Study doi: 10.1007/s10902012-9374-y.
Speicher, B. (1994). Family patterns of moral judgement during adolescence and early adulthood. Journal Developmental Psychology, 30(5).

Stanley, S. F. (1978). Family education to enhance the moral atmosphere of the family and the moral development of adolescents. Journal of Counseling Psychology, 25(2).

Thomas, A. M. (2011). Parent and peer influences their role in predicting adolescent moral values and delinquent behavior (Tesis). Human Development and Family Studies, Colorado State University, Colorado.

Toner, E., Haslam, N., Robinson, J., \& Williams, P. (2012). Character strengths and wellbeing in adolescence: Structure and correlates of the values in action inventory of strengths for children. $J$ Personality and Individual Differences.

Van ljzendoorn, M. H., Zwart-Woudstra, H.A. (1995). Adolescents' attachment representations and moral reasoning. The Journal of Genetic Psychology, 156(3).

West, M., Rose, S. M., Spreng, S., SheldonKeller, A., \& Adam, K. (1998). Adolescent attachment questionnaire: A brief assessment of attachment in adolescence. Journal of Youth and Adolescence, 27(5). 